\title{
Public private partnerships: Can small municipalities participate?
}

\author{
Moira Winch, Ec.D.
}

This paper will attempt to explain in detail how Osgoode Township located in the city of Ottawa developed public-private partnerships to enhance economic viability. It will explain why this alternative was chosen, describe the two partnerships now in place, how they work, and their principal strengths and weaknesses. From the lessons learned the paper will then provide a policy framework for those communities wishing to consider pursuing similar partnerships as a method to sustain economic well-being and to provide innovative solutions to the business of local government in the future.

Keywords: public private partnership, policy, municipal government, Township of Osgoode

Municipalities across Ontario feel the deprivation of reduced or eliminated provincial grants. At the same time they are required to fund new responsibilities "down-loaded" by the province to the municipal sector. As well, taxpayers are angry about the level of taxation from all levels of government, and, since the municipal level is the government body most closely linked to the taxpayer, municipal politicians have been reluctant to increase taxes and face the wrath of those who elect them.

In Osgoode Township, (Population 17,000) a rural/small urban municipality located in the shadow of the City of Ottawa, and located within the Region of Ottawa-Carleton, there is yet another threat to economic well being. The Province of Quebec, with its incentives to business such as tax exemption, subsidized land and labour costs, provides direct competition for new business growth. And, in the northern United States, New York State, which is only a short drive of less than $60 \mathrm{kms}$., represents another giant competitor with numerous incentives for new business.

Osgoode Township does not have serviced industrial land. All lands are serviced privately. However all new commercial and industrial construction is subject to the Ottawa-Carleton Region's development charges. These add significantly to the cost of construction. Osgoode Township, in an attempt to assist and attract new business has waived the Township's development charge. However, rural municipalities located to the south of Osgoode, do not have upper-tier development charges and, therefore, are often able to provide serviced land to new business at very competitive costs, compared to Osgoode.

Osgoode has attempted to counter these competitive disadvantages by being "business-friendly”. Planning and engineering staff, the Chief Administrative Officer and members of Council, all 
work diligently with any business interest, either new or existing, to help cut through the bureaucratic difficulties that often occur as a result of being a small part of a large, predominantly urban, regional municipality. Staff provide funding advice, engineering and planning assistance and discuss marketing and business planning issues with prospective clients. In spite of this pro-business attitude, the ratio of commercial/industrial to residential has dropped in the past ten years from 10 per cent to under 5 per cent.

Minimal business development in a Township like Osgoode obviously leads to higher costs to the residential property owners in order to maintain Township infrastructure. Roads, environmental management, parks, recreation services, fire and by-law enforcement cost more because of the lower commercial/industrial tax base. Increased revenue sources are non-existent.

How to resolve this issue? This paper will attempt to explain in detail how Osgoode Township developed public-private partnerships to enhance economic viability. It will explain why this alternative was chosen, describe the two partnerships now in place, how they work, and principal strengths and weaknesses. From the lessons learned the paper will then provide a policy framework for those communities wishing to consider pursuing similar partnerships.

The title "Real" Public Private Partnerships was chosen because the partnerships entered into by local government are often partnerships with other publicly funded agencies, or associations such as Chambers of Commerce, Business Associations, etc. In both of the examples used in this paper, the public-private partnership is a partnership between Osgoode Township and a private company or companies. Public private partnerships in Osgoode occurred as a result of the leadership of an entrepreneurial mayor, who provided staff with the encouragement to look outside of their own realm for solutions.

\section{Country hill estates}

\section{Description of project}

Country Hill Estates is a rural estate lot residential subdivision located near the Village of Metcalfe, population 1,500. It has quite a history!

First, a lesson in urban planning. In the 1970's, in Ontario, to curb "ribbon development", the Province put in place planning legislation which had the effect of merging two properties owned by the same person into one. This meant that owners of rural subdivisions could not own adjacent lots. To avoid this, many people assigned the ownership of lots to their relatives. Thus, wives, children, brothers and sisters owned individual parcels. This was called “checkerboarding”. This occurred in Osgoode Township in a subdivision of approximately 300 acres. Over a period of years many of these lots did not sell and the Township became the owner 
through tax registration. Since approximately 200 acres of this property contained high quality mineral deposits, the Township amended its Official Plan to allow for future quarry operations.

In close proximity was another parcel of land designated rural, which the owner wished to have designated mineral resource. This parcel was a very rich deposit of aggregate material. However, since it was located in the proximity of several rural subdivisions which had recently been registered, the Township would not change the designation. The owner applied the to Ontario Municipal Board for a decision, and the Board upheld the Township decision. Thus, this parcel of 400 acres remained rural in its designation. The owner, a large road building contractor, determined that given the Ontario Municipal Board's decision the best use of the land would be a rural subdivision similar to those in the neighbourhood, in spite of the rich aggregate mineral deposit on the land. At that time, rural subdivisions were popular and lots sold quickly. However, by the time all of the negotiations had taken place and the studies and paperwork required to bring the land to subdivision registration stage were complete, the economic climate changed. Rural lots were no longer "hot" and there was an oversupply on the market. As well, the Provincial Ministry of Natural Resources was now emphasizing the need to preserve and develop aggregate resource areas in close proximity to large urban centres where the requirement for aggregates was the greatest. Therefore, the owner, whose first priority was road building, not subdividing property, once again turned his thoughts to his primary interest, the more lucrative business of mining aggregates.

Even though the land was now registered as a rural subdivision, the owner applied for an Official Plan Amendment and a Zoning Amendment to take the property back to Mineral Resource with a zoning for a quarry. The Township denied the application. However, since the Province was now promoting the importance of saving mineral resource areas close to urban centres, to provide a continuing source of aggregates for the growing urban area, the Township felt it was unlikely that the Ontario Municipal Board would support the Township's decision, as it had in the past. Legal counsel advised that it would probably cost in the neighbourhood of $\$ 250,000$ to fight this battle at the Board, and it was unlikely the Township would win. Local landowners who had either draft subdivision plans, or registered country estate lot subdivision, already underway, fought this application. They argued that a quarry in close proximity to estate lot development is not compatible and would financially ruin their development plans. Landowners urged Council to take whatever action it could to preserve the peace and quiet of the country estate lot developments. Individuals appealed to Council that their property values would drop, and as well, they would be faced with continuous noise as the quarry churned out ton upon ton of crushed rock. The Township needed a saviour! The Mayor at the time took it upon himself to personally negotiate on behalf of the subdivision owners and rural residents in the area with the road building contractor. Remember the land accumulated by the Township mentioned earlier in this paper? Using this land the Mayor arranged a land swap which provided the road building contractor with property already designated as mineral resource. However, since the Township- 
owned parcel, with high quality mineral resource, was only a 200 acre lot, the Township was required to pay the difference in value, a sum, when all appraisals were complete, of $\$ 600,000$. The deal was approved. The owners of adjacent properties were jubilant and the Township was now the owner of a 400 acre rural estate lot subdivision, registered and ready to go.

By this time it was 1994. These were lean times for lots in rural areas, and, Osgoode already had a significant number of vacant lots owned by local developers and builders. The Township offered the property for sale with a view to recapturing at least the $\$ 600,000$ which had been paid out.

There were no takers!.

In 1996 a local firm came forward with a joint venture proposal. The firm had a road building business and was affiliated with a builder of modular homes. The firm proposed an agreement that would see the Township continue to own the lands, but they would service the subdivision in accordance with the registered subdivision agreement (provide roads, utilities, grading, street lighting, etc). A third partner would build the homes. The two private sector partners would be responsible for marketing the subdivision. The Township agreed that it would receive 27 per cent of the sale price of a lot, but would not receive less than $\$ 10,000$ per lot. This would mean that by the time this 110 lot subdivision sold out completely the Township would have received a minimum of $\$ 1.1$ million.

Was this a good deal for the Township? Some feel it was--it got rid of a liability and has the potential of revenue over a period of years that will recapture the initial $\$ 600,000$ plus interest. It costs the Township between $\$ 35,000$ and $\$ 40,000$ in interest payments per year on this outstanding dept, therefore the sale of three or four lots per year offsets the interest charges. Additional sales would go towards a decreasing the outstanding principal.

Should the Township have taken a loss and sold the property as soon as possible and at least recaptured part of the outstanding cost? A present value of $\$ 600,000$ is only worth $\$ 405,600$ ten years from now using an annual inflation factor of 4 per cent. However, as mentioned earlier, at that time there were no buyers for the registered subdivision, and to bring lots to the market a large influx of capital was required to service the property.

What took place was a joint venture or a strategic alliance, something we hear a lot about in the high tech industry. Each partner brought to the partnership a specific contribution: the Township contributed the land, the construction company provided the services, and the builder builds the houses.

Summary of project 
The public-private joint venture was crafted in late 1996 and servicing began in the summer of 1997. By the fall of 1998 five lots had been sold and three houses built. In 1999 it is expected that another 10 lots will be sold and several houses built. The project was divided into four phases for servicing. By the end of 1999 the second phase will be serviced. The partnership has been successful for all three partners thus far, and with 1999 seeing increased residential starts, it bodes well for the future.

In considering this type of partnership the Township did not just consider the monetary situation. In each of the villages in Osgoode Township there is a need for increased population to ensure viability of the local business sector. Bringing this project on stream increases the demand for local services. As well, local tradesmen are employed to assist the construction of services and new homes. The local economic impact is much broader, of course, owing to the multiplier effect.

\section{Lessons learned}

When breaking new ground in municipal business, it is necessary to evaluate the benefit to the residents of the project. In the case of the Country Hill Estates public-private project several issues should be considered.

Did the municipality seek buyers aggressively? A wider search for a buyer than just the local builders might have been more beneficial in that the entire debt might have been discharged much sooner.

Is being in the home construction business good for a municipality? In 1998 a large group of local builders requested a meeting with the Mayor and Chief Administrative Officer to protest that the municipality, by entering into this joint venture, was competing with the private sector. In their minds this had the effect of driving down lot prices. It is true that no taxes are charged on Township land which could be considered a competitive advantage for the other two partners. However, with respect to lot prices, a survey done by an appraiser hired by the Township revealed that lot prices had dropped in all rural municipalities. A very strong case was made that the Township by retaining ownership of the subdivision, the builders were not required to pay taxes on the vacant land, and were, therefore in a better position to compete in the marketplace. As well, an argument was made that the Township engineer and planner provided free services since this was a Township development. This was not the case, however, as the engineering and planning costs had been paid to the Township by the previous developer prior to registration of the subdivision. These concerns continue to haunt the Township every time a lot is sold in this development and another developer loses a customer for whatever reason. 
Could this confrontation have been avoided? Until very recently Osgoode Township had a history of conducting its business without much consultation with the public. Recent legislation ensures that all municipalities must conduct their business in a much more open regime. This is now the case in Osgoode. However, local developers feel that they were never given a chance to put forward a proposal with respect to Country Hill Estates. They have pointed out to Council that what should have occurred was an open request for proposals which would have allowed all of them an opportunity, either alone, or in groups, to put together a business plan and submit a proposal to the Township. Instead, since the Township did not receive an offer of an outright purchase they chose to accept the first proposal that came in. Perhaps if more proposals had been invited the Township might have been able to sell the land and not be in the development business, competing with private sector builders. At the very least more public consultation should have taken place with the public generally, as well as those with specific interest in the home building industry.

Certainly, the public good was considered. Council felt a need to divest the Township of the $\$ 600,000$ debt and interest payments, as soon as possible. As Richard Barnett notes in Urban Governance and Finance, motivation for privatization includes the ability "to provide a means of financing projects that would otherwise increase the public sector borrowing requirement”.

Only time will tell whether or not this project will work in the Township’s favour. So far it appears that it will..

\section{Springhill landfill site}

\section{Description of project}

Springhill Landfill Site is a natural attenuation landfill site located within Osgoode Township on Springhill Road just east of Regional Road 31, south of the Village of Vernon. It is owned by the Township and has been used by Township residents and businesses for many years. Operation was somewhat informal in the days when all residents were required to take their own garbage to "the dump".

In mid-1996 the Township was called upon by a land owner adjacent to the landfill site to test his well-water, and it was found that the source of contamination was leachate from the site. In reviewing the annual Report done by the Township's environmental engineers for submission to the Ministry of Environment, it was noted that residential waste had, inadvertently, been placed on a part of the site that had been declared unsuitable for such waste. The Township, therefore, was required to fix the problem. Consultation took place with Ministry Officials and environmental consultants. The recommended option was to remove the source of the contamination to another part of the site, to purchase adjacent property to ensure that all 
contamination would be brought under the umbrella of the landfill site, and to drill several new test wells, to monitor leachate movement and concentration. Costs associated with this project were in the neighbourhood of $\$ .5$ million. As well, the Ministry demanded a much more accountable management system for the site, which required the purchase of a large compactor, and the construction and purchase of a weigh scale and a scale house, an additional cost of \$.3 million. These were funds Osgoode Township did not have. Even if this amount was debentured over fifteen years, the cost to Osgoode taxpayers would be significant, and taxes would have to increase to pay interest as well as the principal.

The Township, being within the Region of Ottawa-Carleton, first approached that body for support, since Osgoode was the only municipality within the Region that still had responsibility for solid waste management. It was thought that perhaps the Region would buy the asset from the municipality, resolve the present outstanding issues, and bring the site into its program for solid waste management for the entire Region. However, there was no interest from the Region. The municipality then reviewed non-solicited proposals from two interested businesses, and chose the one from Tomlinson Environment Services (TES).

The Township had established a Waste Management Committee made up of senior staff, and one politician which was assisted by the Township's legal counsel to negotiate a final agreement with TES. This agreement was signed in December 1996.

\section{Highlights of the agreement}

The Manager (TES) would be responsible for cleaning out the waste causing contamination from the area, and moving it elsewhere on the site;

The Manager (TES) would ensure new monitoring wells were constructed in accordance with the Ministry of Environment's requirements in areas that would allow evaluation of groundwater contamination

The Manager (TES) would purchase a new compactor and scale and build a scale house

The Manager (TES) would purchase the property on which the contaminated well was located and ensure the water rights to this property were incorporated into Certificate of Approval given by the Ministry of Environment

The Manager (TES) would manage the landfill site in a positive way and report to the Ministry in accordance with the Certificate of Approval and any other provincial legislation.

The Manager (TES) would purchase environmental insurance for the landfill site. 
The Manager (TES) would set up a "Project Reserve Fund” which would accumulate \$1 million by the time the landfill site was at capacity.

The Manager (TES) would employ all those required to operate the site.

Of course, there had to be some benefit to TES if they were going to provide the above service for the municipality. The conditions included:

Free tipping of waste from the Township’s commercial and industrial customers up to an equivalent amount of residential waste collected from Osgoode residents. TES leased garbage bins to commercial and industrial customers and charged them a fee for collection. TES covers the cost of collection but does not pay to tip at the landfill site until the equivalency factor is met.

TES would be allowed to apply to the Ministry of the Environment to expand the Certificate of Approval. Permission was granted to TES to use a mix of materials for cover material which allowed them to save money, and they were allowed to implement a construction and demolition waste recycling facility on the landfill site. They did not, however, receive permission to expand the usable envelope of the site. (It was anticipated that a construction and demolition recycling facility would be a revenue generator for the partnership.)

The term of the agreement would be until the landfill capacity at the site is exhausted as determined by the Certificate of Approval issued by the Minister of the Environment.

The key consideration was that "the Manager shall receive a Management Fee equal to SIXTY(60 per cent) PER CENT of the net profit generated by the operations of the project as defined and calculated under the terms of this Agreement. The owner shall receive revenues equal to FORTY (40 per cent) PER CENT of the net profit generated by the operations of the project as calculated under the terms of this Agreement” (Township of Osgoode/TES Agreement, Dec. 23, 1966). The agreement goes on to list the specific duties of the manager and the owner.

This agreement provides an opportunity for the municipality to participate in any revenue generated by the partnership after all costs, in accordance with the agreement, are paid. The contract allowed that if there was a deficit in any one year the Township would not be required to participate. It was anticipated that there would be no revenue to the Township in year one, (calendar year 1997). However, due to an special situation that required clean-up of contaminated soils as a result of an oil leak, the Township did receive $\$ 168,000$. In year two, (1998) the Township received $\$ 69,000$ and $\$ 120,000$ is projected for year three (1999). 
Clearly, Council's intention was to have an agreement in place that would alleviate the problems of contamination outside of the envelope of the licensed area of the landfill site, with a minimum cost to the taxpayers of Osgoode Township. To debenture an amount of approximately $\$ 800,000$, which was the up-front cost to TES to purchase equipment and undertake the work, would have put the Township at a disadvantage should any further requirements for major capital expenditures occur. The Township was proud of its "no-debt" legacy. The residents knew their Council kept a tight rein on expenditures and would not have appreciated this new debt load. Council also realized that there were no members of staff with specific expertise for landfill management, and to hire such staff would be costly. The upper tier government, did not express any interest in assisting Osgoode. The deal made was a good one in the minds of all members of Council and the vote, on December 15, 1996, to enter into a partnership agreement with Tomlinson Environmental Services, was unanimous. Not only did it resolve the outstanding issues pointed out by the Ministry of Environment, but it had the opportunity for revenue generation with little input from either Council or staff of the municipality. The Township's legal counsel had worked with the partner's legal counsel to craft an agreement that would benefit both parties.

\section{Summary of the project}

As might be imagined, there was an element of urgency to the contamination problem outlined above. This, along with precise direction from the Ministry of the Environment to provide a weigh scale, a proper compactor, and a better methodology of daily management of the landfill site, made resolution of this problem a high priority for Council. As well, since the leaching problem could only get worse, there was a need to put in place a mechanism to mitigate the contamination without delay.

Although much discussion did take place during regular Council meetings, when the Councillor appointed to the Committee briefed the rest of Council, Council did not make any special attempt to bring the problem to the attention of the general public. No public meetings were held, nor were there any meetings with neighbours to alleviate their fears and help them understand what types of solutions were available, and what choices had to be made. Council approved the agreement written by the lawyers and recommended by the Landfill Committee. This took place in December 1996.

In mid-1997 it was brought to Council's attention that the partner was in the process of buying up all adjacent properties, a total of some three hundred acres. Council questioned this, and were told that it was a security measure for the future, in case of further contamination problems. When questioned about whether TES had expansion in mind, the response was not in the immediate future. In spite of there being an agreement in place and a partnership underway, no consultation had taken place with Council prior to the additional land purchases. 
In November 1997 there was a municipal election. Those running for office were asked about expansion plans and, following advice provided the previous summer, advised the public that there were no plans for expansion at this time. Because there had been comments such as "you gave away our landfill site” from the public, several existing Councillors addressed this issue in their election literature.

It should be noted that during 1997 Council had also determined that beginning in December 1997, there would be a charge for each bag of garbage picked up at curbside and that there would be an expanded blue-box recycling program which, it was hoped, would reduce waste going into the landfill site. While this initiative did not directly relate to the management agreement for the landfill site, constituents married the two, and the notion that "you gave away our landfill site, and now we have to pay for garbage” became a beacon. Those running for office, who were part of the existing Council, tried to make the point that these were separate issues, with the "tag-abag” user-pay simply a means to reduce garbage going to the landfill site, and a fairer way of assessing the costs of garbage collection. Previously, garbage had been assessed across the entire tax base, residential, industrial, commercial and vacant land all paid a share. With the new "user-pay”, only those putting waste at curbside paid the dollar a bag fee. In this way vacant farm land which did not produce garbage and commercial/ industrial/institutional customers who had their own garbage containers, were not charged twice for this service. From a corporate perspective this was an advantage, as you will remember that the agreement allowed TES to tip, free of charge, the same tonnage as that collected from the residential waste stream. The new system reduced the curbside waste by half.

Shortly after the election, the manager, TES, brought to staff a proposal to expand the landfill site, by building an entirely new, completely engineered site adjacent to the existing site. The new site would be located on the lands purchased by TES. Staff, of course, were required to bring this new venture to Council for their consideration. The new venture would increase waste to 100,000 tons tipped per year using the new, fully engineered facility. It was assumed that the existing natural attenuation site would be used for the construction and demolition recycling facility, which process does not have the same aptitude for contamination. Council were somewhat alarmed about this new proposal, in that they had very recently told the public that there were no immediate expansion plans for the landfill site. However, the business case for the new project was such that Council felt it was important to bring to the public the option before it. Council did this in a series of eight public meetings. Each meeting was attended by between 120 to 300 people, many of them very angry as they felt they had been tricked by Council. Councillors had been advised not to speak at the meetings, as this might jeopardize any future negotiations and would likely not be seen as appropriate should the venture proceed to the Ontario Municipal Board. 
After the eight confrontational meetings, at which the public was given the same opportunity to speak as the representatives of TES, Council members determined that they would not support the expansion of the Certificate of Approval for the site to include a new site. Instead, Council convened a Waste Management Task Force to look at all aspects of waste management in the municipality, and to determine the economic viability of the existing partnership. The Task Force will bring its recommendations to Council for consideration in June 1999.

As mentioned earlier, the partnership is still in place and an expected revenue for 1999 is $\$ 120,000$.

\section{Lessons learned}

Waste management, garbage and landfill sites are controversial subjects at the best of times. $\mathrm{n}$ the Springhill situation, with the very best of intentions for the public good, it appears that decisions were made in haste. Given the magnitude of the problems and the long term impacts of the decisions, more time should have been given to a complete, comprehensive investigation of the situation. Consideration should have been given to the environmental, financial and political consequences.

A formal Request for Proposals could have been initiated, once the environmental problems had been determined. These could have included the type of public/private partnership that was adopted, but could have considered other options, such as mechanisms to resolve the problems with precise costs associated with these solutions. In this way, Council would be making a decision based on several options, instead of only one or two, very rough outlines which were submitted.

Prior to signing of any agreement a professional evaluation of costs and benefits should have been provided. In the case of Osgoode, since no staff had the professional credentials to undertake this type of evaluation, a reputable financial firm should have been engaged to do it. In this way, also, all bias is removed.

Because of the political ramifications of anything relating to waste management and landfill sites, Council should have had more, in depth, consultation with the public. This could have been achieved by setting up a Task Force and taking a period of three months to "get the word out" and receive input from the public. There was such urgency to resolve the problem, that it took over the situation. Whereas, in reality, once the property which now contained the contaminated well was purchased, more time could have been taken to receive public input, undertake discussion with the Ministry of the Environment and the Regional Government, before going forward with an unsolicited proposal. 
This partnership has a long lifespan - until the landfill site is full. This has been questioned by many as being unwise. However, since the partner was providing up-front capital to the tune of $\$ 800,000$ there would have to be an appropriate time to recapture the capital investment. As well, proper management of the site was ongoing. The Ministry of the Environment had been critical of the previous management by the Township. Given the "public" aspect of this partnership, perhaps a time frame of fifteen years would have been appropriate, in that it would have allowed a pay-back period for the up-front capital but provides a clear cut exist strategy in the partnership. At that time, if the partnership was positive for both parties, the "contract" could have been extended.

Although the municipality considers the agreement a public/private partnership, the key here being the word "partnership", the private sector partner considers the agreement to be a management agreement, whereby TES manages the landfill site for the Township, proceeds to undertake anything outlined in the agreement, and considers the only requirement to be to ensure that the 40 per cent of net profit is turned over to the Township on an annual basis. On occasion the Township has specifically querried aspects of the agreement which are not being adhered to. However, despite specific conditions in the agreement, whenever they are querried or challenged, TES does comply but considers such demands as onerous. The unwritten message from the private-sector partner is "just leave us alone to get on with our business". Explicitly the Township was told that the partner did not need to clear with the Township the need to travel to investigate new methods of recycling construction and demolition waste, however, when advised that the Township had added two additional wells for screening to the list already in place, the partner indicated very clearly that this was not within the authority of Council or Township staff decision-making.

It is fair to say that during the eight public meetings relating to the proposed expansion project, that TES were subject to intense interrogation, which they felt was completely unfair. The Ministry of the Environment requirements are that only one "public" meeting is required. However, Council determined that a new landfill site adjacent to the existing one was such a controversial project, that they felt the need to go to each community and have an in-depth discussion of the proposed project. Many members of the public asked to speak on the issue, and were granted, by Council, time on the program. These meetings were not required in terms of the specific directions of the Ministry, but were, from a political point of view. An election had just been fought and one of the main issues was the matter of the new partnership at Springhill. At the meetings all in attendance learned a great deal about the workings and problems of the landfill site. Osgoode Township is certainly knowledgeable when it comes to landfill management issues. However, it should be noted that these meetings damaged the partnership, in that TES felt they were put in a no-win position by Council. While this may be true, Council was not aware of the proposed expansion. Council had been put into a very precarious political 
position because of it. The expansion was not part of the partnership program, and all costs related to it were borne by TES.

\section{Policy considerations}

Two examples of public-private partnerships have been detailed. As can be seen this type of municipal endeavour is not without pitfalls. It is a very complex business and one with which municipal authorities are not as yet too familiar. So, what should be addressed in policy formulation relating to the emergence of public-private partnerships?

What is the public benefit? In both of these examples we clearly see that cost savings was a major factor. This small Township was not in a position to borrow significant amounts of money to provide solutions. In order to keep taxes at an affordable level, some other solution was needed. As well, with any environmental project there is the risk assessment. By partnering the risk is split between both partners.

Has the public been consulted? Unfortunately, in neither of the cases was there any real attempt to consult the public in the beginning. Only when faced with a very controversial political situation, did Council initiate public consultation. Had this been initiated prior to an agreement being signed, better understanding of the Township’s position may have been a result.

What solutions were considered? As noted, in both situations, unsolicited proposals were received and acted upon. No Terms of Reference were designed to determine whether others might have provided other options. An opportunity audit could have been undertaken to identify benefits of a partnership. This is a thorough and methodical review of municipal operations to identify opportunities to improve the delivery of a service, or to deliver a desired new service, through the resources of the private sector in a form of partnership.

Who evaluated the solutions? The options provided were evaluated by staff and Council, with legal assistance to put together an agreement once a decision had been reached. Professional environmental engineers provided advice with respect environmental solutions. No detailed financial analysis was undertaken for either partnership. No outside group reviewed the proposals from an unbiased perspective.

Who can be hurt by this solution? Although Osgoode Township did not encounter any significant union collective agreement problems (only one employee was made redundant by the partnership), in larger organizations this could prove challenging.

\section{Policy framework}


- Understand the current environment - what do you have now?

- $\quad$ Define the problem, establish needs and understand options available.

- Confirm the decision to explore public-private partnership.

- Establish clear objectives - where do you want to go- in what time frame - and at what cost.

- Appoint a strong negotiating team and adopt a co-operative or "Partnership" approach.

- Consider stakeholder interests and impacts. Strive for a win-win-win (Council, public, and private sector partner) solution.

- Conduct an extensive public information program in the community. Be able to respond to questions and explain decisions made by Council.

- Undertake a a systematic, fair and unbiased competitive process which is transparent.

- Build trust in the decision making process - empower decisions makers.

- Seek professional assistance when required.

- Ensure the contract or agreement is clear about responsibilities of each party - ensure each partner understands their respective roles.

- Involve unions.

\section{Keys to success of public-private partnerships}

Mr. Larry Wallace, Chief Operating Officer of the City of Atlanta, recently presented to delegates and the Federation of Canadian Municipalities in Halifax regarding a public-private partnership the City of Atlanta has for water and waste water systems. He emphasized the following keys to the success of Atlanta's program:

- starting with a comprehensive objective analysis of the alternative ways to reduce operating costs

- establishing a benchmark for potential savings

- conducting an extensive public information program in the community

- establishing/maintaining integrity of the process 
- dealing with intense media scrutiny

A survey conducted by the Office of the Canada/Nova Scotia Cooperation Agreement to Promote Private Sector Participation in Municipal Infrastructure indicates that municipalities in all Provinces are involved in public private partnerships (see Figure 1). The vast majority of these are in the environmental field in such areas as waste water treatment, sewage disposal, solid waste and water supply and treatment. Generally, the major reasons for involvement with a private sector partner are the need to secure financial assistance and to engage professional expertise not available in the municipality. As well, municipalities are seeking reduced operating costs by partnering with private sector firms whose labour costs are often lower. Most of these projects are large, expensive and complex with a long pay-back schedule. Many partners report "no obstacles" in the undertaking, others note minor concerns that can be resolved. It was interesting to note that while large municipalities dominate the list, some smaller towns and townships, like Osgoode, are also involved in public/private partnerships.

\section{Conclusion}

In conclusion, I quote from the Preface of The “3Ps” of Municipal Infrastructure:

"There is as yet no evidence that partnering is the panacea for all problems plaguing local governments. In part because everyone's busy rethinking the proper role and function of government into the next century (or even just the next few years!), considerable uncertainty remains over where and when to implement public/private solutions. There are uncertainties around how to choose the right candidate project; about the right financing structure; about public education, consultation and inclusion; and about effective negotiation and contract monitoring. And because partnering is an area of policy and practice still very much in its infancy, there are relatively few models or precedents to look for guidance or instruction” (Shaen, 1997).

So what does this have to do with economic development in the Township of Osgoode? We, in small municipalities, see ourselves not just as economic development officers but as community developers. We exercise our expertise to assist the community to work internally for the economic well-being of the whole. We work with Council to create decisions that assist Council's bottom-line - to not increase taxes for either the business or residential sector, and to encompass community health and prosperity. Assuredly, this is what Osgoode Council tried to achieve in crafting two public/private partnerships. Although, Council was new at this type of business, it moved forward and has provided a workable mechanism to resolve two complex and expensive issues. Council has learned along the way, and in future, will incorporate many of the "lessons learned" and will pay heed to the "policy framework" listed above. Both Council and staff at Osgoode feel they were breaking new ground when these two ventures were undertaken. 
Nothing that they have encountered would detract from consideration of yet another venture. Clearly, this Council sees Public/Private Partnerships as a method to sustain economic wellbeing and to provide innovative solutions to the business of local government in the future.

\section{Author's biography}

Moira Winch is currently the Chief Administrative Officer of the Township of Osgoode, an urban/rural municipality in the National Capital area. For twelve years prior, Moira was Township Clerk and Economic Development Officer for the Township of Goulbourn, also in the Ottawa-Carleton Region. Moira has a Master's Degree in Public Administration from the University of Western Ontario and has accreditation from the Association of Municipal Clerks and Treasurers (AMCTO).

\section{Bibliography}

Agreement Between the Township of Osgoode and R.W. Tomlinson Ltd.

Agreement Between The Township of Osgoode, Cornwall Gravel and Guildcrest Homes.

Barnett, Richard, Urban Governance and Finance.

Federation of Canadian Municipalities Conference, Alternative Project Delivery: Myths and Realities, Halifax, June 1999.

Federation of Canadian Municipalities Conference, Water and Wastewater: Public Private Partnerships: Procurement Planning for Municipal Officials, Halifax, June 1999.

Mississauga’s New Hershey Centre, Municipal World, January 1999.

Osgoode Township Council, Various papers, documents and minutes.

Shaen, Michael (ed.), The “3Ps” of Municipal Infrastructure, Public Policy Forum, September 1997.

Wallace, Larry, The City of Atlanta Case Study, April 1999.

\section{Interviews}


Interviews with Council Members; R. Mills, P. Webber, Legal Counsel for Osgoode Township; R.W. Tomlinson \& Ron Tomlinson, Tomlinson Environmental Services, Osgoode Township staff. 